\section{Studia \\ z Filologii Polskiej \\ i Słowiańskiej}

DOI: $10.11649 / \mathrm{sfps} .2238$
Studia z Filologii Polskiej i Słowiańskiej, 56

Warszawa 2021

Article No. 2238

Citation:

Краснобаєва-Чорна, Ж. В. (2021). Психофізіологічний патерн емоції презирства: Актуалізація інваріантних ознак в українській фразеологіï. Studia z Filologii Polskiej i Stowiańskiej, 56, Article 2238. https://doi.org/10.11649/sfps.2238

Krasnobaieva-Chorna, ZH. V. (2021). Psykhofiziolohichnyı̌ patern emotsiï prezyrstva: Aktualizatsiia invariantnykh oznak v ukraïns'kiü frazeolohiï. Studia z Filologii Polskiej i Stowiańskiej, 56, Article 2238. https://doi.org/10.11649/sfps.2238

Жанна В. Краснобаєва-Чорна

(Донецький національний університет імені Василя Стуса)

\title{
Психофізіологічний патерн емоції презирства: актуалізація інваріантних ознак в українській фразеологї̈
}

Сучасні мовознавчі студіювання емоції презирства грунтовані на постулатах емотивної лінгвістики та здебільшого презентують два напрями. Перший, дискурсивний, охоплює презирство як складник конфліктного дискурсу (Серякова, 2015); прагматичні особливості репрезентації презирства в сучасному англомовному політичному дискурсі (Станко \& Чендей, 2018); комунікативну стратегію презирства в англомовному кінодискурсі (Гулієва, 2016); інвективну специфіку фразеологізмів із соматичним компонентом на позначення презирства (3-поміж інших семантичних полів) польської та російської мов (Klyus, 2018, с. 168) тощо. Другий напрям, семантико-когнітивний, вивчає концепт 'презирство' як складник пейоративної конотації фразеологізмів (Лескина, 2008); концепт 'презирство' як репрезентант емоційного стану художнього персонажа у жіночому романі (Степанюк, 2016); концепт 'презирство’ як номінант деструктивної емоції (Волкова \& Панченко, 2018) тощо.

This is an Open Access article distributed under the terms of the Creative Commons Attribution 3.0 PL License (creativecommons.org/licenses/by/3.0/pl/), which permits redistribution, commercial and non-commercial, provided that the article is properly cited. (c) The Author(s) 2021.

Publisher: Institute of Slavic Studies, Polish Academy of Sciences

[Wydawca: Instytut Slawistyki Polskiej Akademii Nauk] 
На думку А. Рейтера, проблема мови й емоцій вимагає обов’язкової апеляції до здобутків психології з метою окреслення вимірів концептуалізації емоцій (Rejter, 2010, с. 79). Дослідник також зауважує, що називання емоцій пов'язане з етимологією, лексикою, фразеологією, а вираження емоцій - з вербальними (фонема $\rightarrow$ морфема $\rightarrow$ лексема $\rightarrow$ речення $\rightarrow$ текст) та невербальними (міміка, жест) засобами (Rejter, 2010, с. 78). О. Ясєльска наголошує на важливості репрезентативної функції мови для стабілізації «чуттєво-афективного» переживання емоцій (Jasielska, 2015, cc. 255-256). У такий спосіб, актуальність статті мотивована недостатнім рівнем опрацювання емоції презирства у рамах фразеологічної емотиології та зумовлена відсутністю комплексного аналізу фразеологічних засобів української мови, що відображають презирство.

Мета статті: визначити специфіку актуалізації інваріантних ознак психофізіологічного патерну емоції ${ }^{1}$ презирства в українській фразеології. Успішна реалізація мети передбачає опрацювання таких завдань: 1) окреслити комплекс пантомімічного вираження презирства у фразеології; 2) схарактеризувати вегетатику презирства у фразеології з опертям на тріаду ворожості 'гнів - відраза - презирство'; 3) простежити психічні особливості конфронтації та конфліктності як проявів ворожості у рамах презирства.

Об'єктом дослідження виступає емоція презирства. Предметом - фразеологічні одиниці (далі ФО) на позначення презирства в українській мові. Матеріал дослідження становлять 30 фразеологізмів із семантикою презирства та 165 мікроконтекстів їхнього вживання. Основний ілюстративний корпус формують 564 фразеологізми ${ }^{3}$ на позначення

1 Під психофізіологічним патерном емоції розуміємо набір стереотипних фізіологічних, психологічних, поведінкових реакцій або послідовностей дій суб’єкта емоції.

2 Під фразеологічними одиницями, за В. Ужченком, розуміємо «надслівні, семантично цілісні, відносно стійкі (з допустом варіантності), відтворювані й переважно експресивні одиниці, які виконують характеризуючо-номінативну функцію» (Ужченко, 2003, с. 26).

3 Ілюстративний корпус ФО на позначення фундаментальних емоцій людини формують фразеологізми із семантикою: вини (27 ФО і 66 мікроконтекстів), відрази (23 ФО і 40 мікроконтекстів), гніву (61 ФО і 215 мікроконтекстів), зацікавлення (44 ФО і 188 мікроконтекстів), збентеження (64 ФО і 223 мікроконтексти), здивування (75 ФО і 237 мікроконтекстів), презирства (30 ФО і 165 мікроконтекстів), радості (49 ФО і 265 мікроконтекстів), сорому (41 ФО і 129 мікроконтекстів), страждання (54 ФО і 200 мікроконтекстів), страху (96 ФО і 405 мікроконтекстів). 
фундаментальних емоцій людини (вина, відраза, гнів, зацікавлення, збентеження, здивування, презирство, радість, сором, страждання, страх), дібраних шляхом суцільного обстеження з академічного словника фразеологізмів української мови, а також понад 2000 мікроконтекстів їхнього вживання. До аналізу в статті залучені також ФО із семантикою гніву та ФО із семантикою відрази (як репрезентанти тріади ворожості 'гнів - відраза - презирство'). Мета й завдання дослідження зумовили необхідність застосування низки загальнонаукових методів, а саме спостереження, аналізу та синтезу, описового, елементів статистичного, використаних для систематизації й об'єктивного опису матеріалу. Серед комплексу спеціальних методів застосовано методи компонентного та контекстуально-інтерпретаційного аналізу, параметричний аналіз семантичної структури ФО (з актуалізацією оцінного й емотивного складників) для виявлення специфіки функціювання ФО із семантикою презирства в українській мові.

Методологійну базу становлять основні положення психології емоцій (Изард, 2009; Ильин, 2015) та фразеологічної емотиології (Bogacz, 2015), лінгвокультурологіï (Jakubowska-Krawczyk та ін., 2016), оцінної семантики (Wierzbicka, 1999) й аксіофраземної прагматики (Краснобаєва-Чорна, 2020).

\section{Кваліфікаційні ознаки емоції презирства у психології}

К. Ізард розглядає презирство як негативний емоційний стан, що виникає в міжособистісних взаєминах і породжений неузгодженістю життєвих позицій, поглядів і поведінки суб'єкта з життєвими позиціями, поглядами і поведінкою об'єкта почуття (Изард, 2009, с. 287). Останні видаються суб’єту не відповідними прийнятим моральним нормам і етичним критеріям. $Є$. Ільїн під презирством розуміє соціальну огиду до людини, спричинену негідним вчинком (Ильин, 2015, с. 280). Специфіка емоції полягає в тому, що вона не зникає безслідно, а переходить в стійке негативне ставлення до об'єкта почуття. Д. Дубравін інтерпретує презирство як отруйну емоцію, як почуття повної неповаги, зневаги, що виникає до людини або групи людей на основі певних особистісних якостей, вчинків або переконань (Дубравин, 2018, с. 119).

Психофізіологічний патерн емоції презирства визначуваний комплексним пантомімічним вираженням, незначними змінами вегетатики з актуаліза- 
цією 'холоду’ та містить дві основні ознаки: перевагу і ворожість. Свідомість переваги суб'єкта над об'єктом (у моральному, культурному або фізичному відношенні) може виявлятися: а) зверхністю, нерівністю та дистанціюванням, що зумовлені почуттями цінності та значущості «Я» суб'єкта порівняно 3 «Я» об’єкта (суб'єкт створює нерівність, ставить себе вище за об’єкт і свідомо дистанціюється від нього); б) відсутністю поваги до об’єкта, байдужістю.

Прояв ворожості (див. термін «тріада ворожості 'гнів - відраза презирство’» ${ }^{4}$ (Изард, 2009, с. 286)) суб’єктом до об’єкта грунтований на понятті «перемога», що позиціонується як фізичні, вербальні й уявні переваги однієї людини перед іншою. При цьому «перемога» передбачає наявність переможця і переможеного: перший починає ставитися до другого з презирством, що спричиняє конфронтацію, конфліктність.

\section{Пантоміміка презирства у фразеології}

Комплекс пантомімічного вираження презирства у фразеології містить такі складники:

1) суб'єкт презирства випростовується, трохи відкидає голову назад і дивиться на об'єкт презирства ніби зверху вниз. У такий спосіб актуалізується семантична опозиція 'верх - низ':

а) суб'єкт презирства корелює з локусом 'верх': піднімати (підіймати, підносити і т. ін.) / підняти (підійняти, піднести і т. ін.) [догори] носа (ніс) ('гордовито, самовпевнено триматися, ставитися до інших зневажливо' (СФУМ, 2003, с. 511)); дивитися (поглядати) згори (зверху) вниз (звисока, зверхньо) ('зневажливо, зверхньо ставитися до кого-небудь' (СФУМ, 2003, с. 198)); високо нестися ('поводитись зарозуміло, погордливо, зверхньо, зневажливо ставлячись до інших' (СФУМ, 2003, с. 434)); задирати (піднімати) / задерти (підняти) хвіст (хвоста) [угору] зневажл. ('поводитися гонористо, самовпевнено, ставлячись до всіх зверхньо, з презирством' (СФУМ, 2003, с. 243)):

${ }^{4}$ Найбільш значуще місце в комплексі ворожості посідають емоції гніву, відрази та презирства. Саме вони впливають на перцептивні процеси та сприяють виникненню образів і думок, співзвучних з афектом, внаслідок чого і виникає ворожість (Изард, 2009, с. 286). 
(1) [Варка:] Бундючилися супроти нас люде [люди], і тепер і ми підіймемо догори носа (М. Кропивницький);

(2) Юруш, сміючись, простяг свою пухку білу долоню. [...] Циганка подивилась та й каже: «Ти високо несешся, але швидко низько впадеш, бо живеш неправдою» (I. Нечуй-Левицький);

(3) Мальований уважно слухав і весь час кивав головою. - Був я на вашому складі. Ти вже занадто хвіст підняв. На роботі не сидиш, за тебе завідуючий облік продукції веде (А. Хижняк);

б) об'єкт презирства корелює з локусом 'низ': топтати (підтоптувати) / nidmonmamu niд ноги (2) ('не рахуватися з ким-небудь, ганьблячи, зневажаючи когось' (СФУМ, 2003, с. 716)):

(4) Та він мовчки усіх вас гнітить, під ноги собі топче (Марко Вовчок);

(5) А він [Нечай] не хотів утікати, «свою славу козацьку під ноги топтати». І клав ворогів, як снопики (Т. Масенко);

2) суб'єкт презирства трохи піднімає брови і верхню губу (або стискає куточки губ): кривити рот (губи, уста) ('ставитися до кого-, чого-небудь зневажливо, зверхньо і т. ін.' (СФУМ, 2003, с. 313)); извіркати через губу ('ставитися до чогось з презирством; нехтувати чим-небудь' (СФУМ, 2003, с. 756)):

(6) Вона ходила змалку на завод

I на хліб свій чорний не кривила рот (Д. Павличко);

(7) - Та ти ж, хлопче, любуйсь теперішнім нашим життям, молись на його [нього], тішся ним, уважай його, а не цвіркай через губу на все [...] (Народне оповідання);

3) суб'єкт презирства відвертає обличчя від об’єкта презирства: вернути (відвертати) ніс (носа, бізіономію, зневажл. рило, пику) (2) ('уникати зустрічей, спілкування з ким-небудь, виявляючи зверхність, зневагу і т. ін.' (СФУМ, 2003, сс. 56-57)):

(8) Вона вже й по вулиці носа верне, обминає мене десятою дорогою, наче я каторжна якась чи заразна (В. Кучер);

5 Цифри в дужках указують на значення багатозначної ФО, подане в словнику. Якщо фразеологізм однозначний, числовий показник не використовується. 
(9) Перш усього й тут [у пресі] треба протекцію, рекламу, а од мене тепер вернуть рило деякі навіть із моїх попередніх приятелів (М. Драгоманов);

4) суб’єкт презирства дивиться «убивчим» поглядом на об’єкт презирства: обдавати / обдати очима (поглядом) ('промовисто дивитися на когось, передаючи певні почуття' (СФУМ, 2003, с. 446)):

(10) Пувичка [...] підійшов ще ближче до Альоші, обдаючи його нахабним, зневажливим поглядом (І. Микитенко).

Отже, комплекс пантомімічного вираження презирства (зневаги, байдужості) у фразеології представлений кінематичними фразеологізмами ${ }^{6}$ : мімічними (соматизми рот / губи / уста, ніс, обличчя / бізіономія / зневажл. рило, пика), миремічними (соматизм очі), корпоральними (соматизми спина / плечі, спина / потилиия, хвіст, ноги). Узагальнену репрезентацію пантомімічного вираження презирства в статті унаочнено в Таблиці 1.

Таблиця 1. Пантомімічне вираження презирства у фразеології

\begin{tabular}{|c|c|c|c|}
\hline Емоція & $\begin{array}{l}\text { Різновид кіне- } \\
\text { матичних ФО }\end{array}$ & Соматизм & $\begin{array}{l}\text { Кінематичні рухи, } \\
\text { зафіксовані у ФО }\end{array}$ \\
\hline Зневага & \multirow{4}{*}{ мімічні } & $\begin{array}{l}\text { рот / губи / } \\
\text { уста }\end{array}$ & кривити \\
\hline Зневага & & ніс & $\begin{array}{l}\text { піднімати (підіймати, підносити) / } \\
\text { підняти (підійняти, піднести) }\end{array}$ \\
\hline Зневага & & нiс & вернути (відвертати) \\
\hline Зневага & & $\begin{array}{l}\text { фізіономія / } \\
\text { рило, пика }\end{array}$ & вернути (відвертати) \\
\hline
\end{tabular}

${ }^{6}$ Г. Демиденко кінематичні фразеологізми визначає як «стійкі словосполучення, план вираження яких репрезентований різними невербальними засобами маніфестації міжособистісної взаємодії, тобто будь-якими комунікативно значущими рухами» (Демиденко, 2016, с. 46) і зараховує їх до паралінгвальних фразеологізмів. Виокремлення кінематичних ФО з-поміж паралінгвальних зворотів видається можливим, на думку дослідниці, внаслідок таких особливостей: а) наявність соматичних компонентів, що кваліфікують рухову активність мовця (голова, шия, плечі, руки, пальці, ноги; обличчя, очі, рот, вуха, ніс); б) вербалізація комунікативно значущих дій, які мають свої конфігурації у просторі, тобто певне розміщення тіла, амплітуду руху, динаміку, силу тощо; в) належність до різних концептуальних систем, адже, з одного боку, це - фізичні рухи, з іншого, - абстрактні поняття, що позначають здебільшого психічний стан суб’єкта (Демиденко, 2016, с. 47). 


\begin{tabular}{|c|c|c|l|}
\hline Емоція & $\begin{array}{c}\text { Різновид кіне- } \\
\text { матичних ФО }\end{array}$ & Соматизм & $\begin{array}{c}\text { Кінематичні рухи, } \\
\text { зафіксовані у ФО }\end{array}$ \\
\hline Різні емоції & миремічні & очі & обдавати / обдати \\
\cline { 1 - 3 } $\begin{array}{c}\text { Байдужість, } \\
\text { зневага }\end{array}$ & \multirow{2}{*}{ корпоральні } & $\begin{array}{c}\text { спина / поти- } \\
\text { лиця }\end{array}$ & показувати / показати \\
\cline { 1 - 3 } Презирство & хвіст & $\begin{array}{l}\text { задирати (піднімати) / задерти } \\
\text { (підняти) }\end{array}$ \\
\cline { 1 - 1 } Зневага & ноги & топтати (підтоптувати) / підтоптати \\
\hline
\end{tabular}

\section{Вегетатика презирства у фразеології}

Простежити особливості репрезентації вегетатики презирства у фразеології видається можливим лише у порівнянні з емоціями гніву та відрази як складників тріади ворожості 'гнів - відраза - презирство', де презирство визначуване як «холодна» емоція, оскільки вона супроводжувана девальвацією об’єкта презирства та відчуженням від нього (Изард, 2009, с. 288) (пор. також: температурна метафора в атрибутивних характеристиках 'крижане презирство’ або 'презирливо-холодний погляд’ (Волкова \& Панченко, 2018, c. 183)). Емоція презирства порівняно з гнівом і огидою визначувана незначними змінами вегетатики суб’єкта (див. також Szerszunowicz, 2011, с. 254), тобто найнижчим рівнем фізіологічного збудження, що знаходить відображення і у фразеології. Аналіз зібраного матеріалу дає змогу визначити, які якісні та кількісні переваги мовців відбито в українській фразеології, й цілком підтверджує тезу А. Спагінської-Прушак, що фразеологія нерівномірно покриває референтну, концептуальну сфери мови (Spagińska-Pruszak, 2003, c. 20). Так, ілюстративний матеріал засвідчує, що відраза може викликати:

a) нудоту: до нудоти ('дуже, надзвичайно, великою мірою (про те, що набридло, приїлось, викликає роздратування)' (СФУМ, 2003, с. 442)); вивертати / вивернути нутрощі (нутро, кишки) ('викликати велику огиду, нудоту і т. ін.' (СФУМ, 2003, с. 64));

б) оскому: оскома на зубах ('у когось виникає відраза до чого-небудь; неприємно, бридко від чогось' (СФУМ, 2003, с. 469));

в) утрату автоматизму дихання, що супроводжується неприємними та болючими відчуттями в горлі: стати / стояти кісткою в горлі (поперек горла) (3) ('зробитися остогидним, ненависним кому-небудь' 
(СФУМ, 2003, с. 692)); стояти / стати кілком (колом) в горлі (2) ('дуже набридати, остогидіти' (СФУМ, 2003, с. 694));

г) нервове збудження: втрачати (губити) / втратити (загубити) рівновагу ('перебуваючи в стані нервового збудження, хвилювання, роздратування і т. ін.; виявлятися нездатним зберігати спокій, самовладання, терпіння' (СФУМ, 2003, с. 137)).

Вегетатика гніву у фразеології представлена:

а) прискореним серцебиттям: скипіло (обкипіло) серие (2) ('хто-небудь гнівається, сердиться на когось, щось, обурюється з приводу чогось' (СФУМ, 2003, с. 228)); кров кипить (закипає, вирує і т. ін.) / закипіла (завирувала) [ $у$ жилах (у скронях)] ('хто-небудь перебуває в стані сильного збентеження, гніву, обурення і т. ін.' (СФУМ, 2003, с. 315));

б) утрудненням дихання: важким (недобрим) духом дихати ('дуже сердитися, гніватися, злитися на когось' (СФУМ, 2003, с. 200));

в) жаром: як (мов, наче і т. ін.) ошпарений (обпарениц̆, опарений і т. ін.) [окропом] (1) ('дуже збуджений, знервований, розгніваний і т. ін.' (СФУМ, 2003, с. 479));

г) нервовим збудженням: виводити / вивести з рівноваги (2) ('своєю поведінкою змушувати кого-небудь нервувати, викликаючи почуття гніву, роздратування і т. ін.' (СФУМ, 2003, с. 65)); виводити / вивести з себе; вивести з терпцю ('своєю поведінкою змушувати кого-небудь нервувати, викликаючи почуття злості, гніву, роздратування і т. ін.' (СФУМ, 2003, с. 65));

г) онімінням: відбирати (віднімати) / відібрати (відняти) мову (1) ('хто-небудь втрачає здатність говорити від несподіванки, здивування, хвилювання, переляку, гніву і т. ін.' (СФУМ, 2003, с. 95)).

\section{Конфронтація та конфліктність презирства як вияви ворожості}

Презирство постає також як емоційно-конфронтаційна реалізація комунікативного наміру суб'єкта висловити, здебільшого, негативне почуття-ставлення (презирство, неповагу, зневагу, ненависть тощо), грунтоване на негативній суб’єктивній оцінці об’єкта (Гнєзділова, 2007; 
Гулієва, 2016). Під час реалізації цієї стратегії широко застосовуваним $\epsilon$ психологічний вплив - тиск на об’єкт презирства за допомогою інтонації й голосу (контексти 11-13), погляду (контексти 14-15), посмішки (контексти 16-17) тощо:

(11) - Перестаньте плескати язиком! Мужчина називається! - з презирством кинула Оксана (П. Автомонов);

(12) - Та й та гарна! То єхида-лисиця, укусе [укусить] й меду дасть, призро [презирливо], гидливо якось одказала Параска (Панас Мирний);

(13) - Потрібна мені ваша Окунівка, мов зайцеві бубон! - презирливо фиркнув Левко (М. Стельмах);

(14) А якщо ви [...] скажете, що Одеса «так собі» - то він [одесит] огляне вас презирливо й викине свого останнього козиря: - Так собі? А море?! (Ю. Яновський);

(15) Григорій майже з презирством дивиться на кожну дівчину. Він уважає себе вільним козаком (М. Стельмах);

(16) Зневажливо осміхнувся [Іванчик] до мене, ніби сказав: «Бідолашний! I чого ти до неї пнешся? Адже тобі тут не світить!» (Я.Баш);

(17) Він зневажливо посміхався собі в вуса, аж Тимофій Гречко гукнув до нього: - А ти, холуй, чого хахи строїш? Ще засмієшся на кутні! (Ю. Смолич).

Вектор на негативну оцінку об’єкта в рамах аналізованої проблематики презентує малочисельна група ФО з маркером 'плювок': плювати / плюнути (наплювати) в криницю ('виявляти неповагу до кого-небудь' (СФУМ, 2003, с. 521)); плював я; плювати я хотів ('уживається для вираження нехтування ким-, чим-небудь, презирства, байдужості до когось, чогось' (СФУМ, 2003, с. 784)):

(18) Боявся [бригадир], видно, що тепер вона нав'язуватиметься йому, відбиватиме від жінки. - Можеш не боятись, - посилала вона в думці йому своє презирство. - Плювала я на тебе (О. Гончар).

Комунікативна стратегія презирства у фразеології трактується як непідготовлена мовленнєва діяльність в емоційно-детермінованій ситуації, що виникає в результаті спонтанного прояву емоцій (незадоволення, обурення, зневаги тощо) з актуалізацією фразеологізмів вигукового різновиду. Ці фразеологізми виражають побажання чогось поганого або 
бажання позбутися когось, чогось та репрезентують очний (конфронтаційність спрямована на співрозмовника) і заочний (конфронтаційність спрямована на третю особу) типи презирства: бодай (щоб) тебе (його, вас, їх і т. ін.) взяла лиха година, лайл. ('уживається для вираження незадоволення, обурення ким-, чим-небудь, зневаги до когось, чогось або недоброго побажання комусь' (СФУМ, 2003, с. 153)); щзоб [тобі (йому, їм і т. ін.)] дихати не дало, лайл.; щзоб так по правді дихав, лайл.; нехай (хай) лизень (лиз, рідше лизь і т. ін.) злиже (лизне), лайл. ('уживається для вираження незадоволення, зневаги до кого-небудь, побажання чогось поганого' (СФУМ, 2003, сс. 187, 200, 334)); бодай (хай би, нехай би) грецьь спалив у діжi, лайл., перев. жарт. ('уживається для вираження незадоволення ким-, чим-небудь, зневаги до когось, чогось, бажання позбутися когось, чогось' (СФУМ, 2003, с. 168)):

(19) - Грішу! - подумав Харитон. - А все оті цокотухи розворушили мої думки, згадали мені про Онисю. А, бодай вас лиха година взяла! (І. Нечуй-Левицький);

(20) - А те приключилось, що твій бойовий побратим усі мої нетрудові заощадження викрав із матраца, хай би його грець спалив у діжі (Є. Гуцало);

(21) - Козаки сидять згорнувши руки! - каже Шрам. - Щоб ви так по правді дихали. Коли 6 не козаки, то давно $б$ вас чорт ізлизав (П. Куліш).

3 основних способів керування конфліктом (за Серякова, 2015, с. 79) у фразеології представлені:

а) плювок (у вічі, в очі, межи очі; в обличчя, в лице, в пику; в душу), що позиціонується як обсцентна дія та супроводжується образою: плювати / плюнути (наплювати) в вічі (в очі, межи очі і т. ін.) ('виражати зневагу, презирство до кого-небудь; ображати' (СФУМ, 2003, с. 521)); плювати / плюнути (наплювати) в обличчя (в лице, в пику і т.ін.) ('зневажати, ображати, принижувати когось' (СФУМ, 2003, с. 521)); плювок у душу ('образа, зневага, що зачіпає найдорожче' (СФУМ, 2003, c. 521)):

(22) - Коли ж пан сотник до тебе підійде, щоб шлюб приньмати [приймати], то тут і відкинься. - Отеє справді, що так, - каже Олена, - таки тут йому межи очі і плюну (Г. Квітка-Основ’яненко); 
(23) - Це не критика, а наклеп, - сказав Максим. - Мені плюють в обличчя, а я повинен усміхатися! (М. Зарудний);

(24) - Німці в пику плюють, а я витрусь рукавом і знову зуби скалю (І. Цюпа);

(25) Криві посмішки одного, другого, косий погляд головного агронома - це було для нього, як плювок у душу (Є. Журахович);

б) загроза поглядом: спопеляти / спопелити очима (зором) ('дуже гнівно, презирливо дивитися на кого-небудь' (СФУМ, 2003, с. 684)):

(26) - Як вас величати? - спитав винахідник Жора, спопеляючи очима Джо Дассена на кофтинці феї (А. Крижанівський);

в) фізичний вихід із ситуації: повернутися / рідко повертатися спиною (спинами, плечима і т. ін.) ('виявити байдужість, зневагу і т. ін. до кого-, чого-небудь, знехтувати ким-, чим-небудь' (СФУМ, 2003, с. 524)); показувати / показати спину (потилиию) (2) ('відвертатися або іти геть, виявляючи зневагу до кого-небудь' (СФУМ, 2003, с. 534)); обертатися / обернутися спиною (1) ('зневажливо, зверхньо ставитися до когось, ігнорувати когось, щось; не зважати на кого-, що-небудь' (СФУМ, 2003, с. 448)):

(27) - Люди повернулися до них спинами... А оті запроданці нічого не бачать із своїх нір і гадають, що вони мають на людей вплив... (М. Ю. Тарновський);

(28) - От народжує типів епоха, - сказав Баглай до архітектора і з неприхованою, якоюсь навіть бридливою зневагою відвернувся від Лободи. I військкоменко теж одразу спину показав на знак презирства (О. Гончар);

(29) - Саво! Не обертайся спиною до людей! - вслід гукнув Гура (С. Чорнобривець).

\section{Висновки}

Презирство - негативна емоція, здатна переходити в стійке негативне ставлення суб’єкта до об’єкта на грунті невідповідності їхніх життєвих настанов, поглядів, поведінки, вчинків, особистісних якостей тощо. Комплекс пантомімічного вираження презирства (зневаги) 
у фразеології цілком відповідає крос-культурним студіюванням базових емоцій і репрезентований кінематичними фразеологізмами: мімічними (соматизми рот / губи / уста, ніс, обличчя / фізіономія / зневажл. рило, пика), миремічними (соматизм очі), корпоральними (соматизми спина / плечі, спина / потилиия, хвіст, ноги). Презирливе ставлення до об'єкта корелює з 'гордістю / самовпевненістю / зневажливістю'; 'зневажливістю / зверхністю'; 'зарозумілістю / погордливістю / зверхністю / зневажливістю'; 'гонористістю / самовпевненістю / зверхністю', 'ганьбою / зневажливістю', 'нехтуванням'. Віднаходить підтвердження і теза про те, що презирство визначуване незначними змінами вегетатики та найнижчим рівнем фізіологічного збудження порівняно з емоціями гніву й огиди.

У фразеології зафіксовані основні психічні ознаки емоції презирства перевага та ворожість. Перевага, позиціонована як нерівність і дистанціювання, виражається здебільшого корпоральними фразеологізмами з актуалізацією семантичної опозиції 'верх - низ', де суб’єкт презирства корелює з локусом 'верх', а об’єкт презирства - з локусом 'низ'.

Ворожість представлена як емоційно-конфронтаційна реалізація комунікативного наміру суб'єкта висловити очно / заочно презирство (зневагу, незадоволення, обурення) з опертям на фразеологізми вигукового різновиду із семами 'побажання чогось недоброго, поганого' і 'бажання позбутися об'єкта'. 3-поміж способів керування конфліктом у дослідженні зафіксовані плювок (у вічі, в очі, межи очі; в обличчя, в лице, в пику; в душу) як маркер презирства, зневаги, образи, приниження; загроза поглядом як маркер презирства та гніву; фізичний вихід із ситуації як маркер зневаги, байдужості, нехтування, ігнорування, що підтримують деструктивну поведінку в комунікації та актуалізують знецінення, деперсоналізацію об'єкта презирства. Останнє уможливлює зарахування презирства до деструктивних емоцій.

Перспективу дослідження вбачаємо в подальшому виявленні фразеологічної специфіки психофізіологічного патерну презирства в зіставному аспекті, а також у визначенні особливостей фразеологічної репрезентації тріади ворожості ‘гнів - відраза - презирство’ у рамах деструктивної комунікації. 


\title{
Скорочення
}

\author{
жарт. - жартівливе \\ зневажл. - зневажливе \\ і т. ін. - і таке інше \\ лайл. - лайливе \\ перев. - переважно \\ сл. - слово \\ ФО - фразеологічна одиниця \\ ФСУМ - Словник фразеологізмів української мови (Винник, 2003)
}

\section{Бібліографія}

Волкова, Я., \& Панченко, Н. (2018). Дискурсивная вариативность концептов деструктивных эмоций. Вестник Российского университета дружбы народов: Лингвистика, 22(1), 175-194. https://doi.org/10.22363/2312-9182-2018-22-1-175-194

Гнєзділова, Я. (2007). Емоційність та емотивність сучасного англомовного дискурсу: Структурний, семантичний і прагматичний аспекти [Doctoral dissertation]. Київський національний лінгвістичний університет.

Гулієва, Д. (2016). Комунікативна стратегія презирства: На матеріалі англомовного кінодискурсу. Science and Education: A New Dimension: Philology, 25(105), 41-45.

Демиденко, Г. (2016). Паралінгвальні фразеологізми в украӥнській етнокультурі. НПП Астерікс. Дубравин, Д. (2018). Психология эмоций: Чувства под контролем. Агентство “ІРІО”.

Изард, К. (2009). Психология эмоций. Питер.

Ильин, Е. (2015). Психология общения и межличностных отночений. Питер.

Краснобаєва-Чорна, Ж. (2020). Вторинна знакова система ціннісної картини світу у фраземіці. ТОВ “ТВОРИ”.

Лескина, С. (2008). Концепты безразличия и презрения как составляющие пейоративной коннотации английских и русских фразеологизмов. Филологчческие науки: Bопросы теории и практики, 2008(2(2)), 65-67.

Серякова, И. (2015). Коммуникативный менеджмент конфликтного дискурса. Science and Education: A New Dimension: Philology, 2015(9(44)), 78-82.

Станко, Д., \& Чендей, Н. (2018). Прагматичні особливості репрезентації презирства у сучасному англомовному політичному дискурсі. Сучасні дослідження з іноземної філологіï, 2018(16), 148-155.

Степанюк, М. (2016). Репрезентація емоційного стану художнього персонажа ужіночому романі: Лінгвокогнітивний і гендерний аспекти: На матеріалі романів Ш. Бронте ma E. Бронте [Doctoral dissertation]. Херсонський державний університет.

Ужченко, В. (2003). Східноукраїнська фразеологія. Альма-матер. 
Bogacz, A. (2015). Emocje negatywne we frazeologii angielskiej i polskiej w ujęciu kognitywnym. Retrieved from http://repozytorium.ur.edu.pl/handle/item/1202

Jakubowska-Krawczyk, K., Olechowska, P., Romaniuk, S., \& Zambrzycka, M. (Eds.). (2016). Ciało i tożsamość w ukraińskiej kulturze, sztuce, literaturze, języku. Katedra Ukrainistyki Uniwersytetu Warszawskiego; Uniwersytet Przykarpacki im. Wasyla Stefanyka.

Jasielska, A. (2015). Pozadosłowne rozumienie emocji. Poznańskie Studia Slawistyczne, 2015(9), 255-274. https://doi.org/10.14746/pss.2015.9.15

Klyus, J. (2018). Inwektywy związane z nazwami części ciała we frazeologii polskiej i rosyjskiej: Analiza leksykalno-semantyczna. Językoznawstwo, 2018(1(12)), 145-170. https://doi.org /10.25312/2391-5137.12/2018_145-170

Rejter, A. (2010). Język a emocje w ujęciu glottodydaktycznym. In A. Achtelik, M. Kita, \& J. Tambor (Eds.), Sztuka i rzemiosło: Nauczyć Polski i polskiego (Vol. 2, pp. 75-83). Wydawnictwo Uniwersytetu Śląskiego; Wydawnictwo Gnome.

Spagińska-Pruszak, A. (2003). Intelekt we frazeologii polskiej, rosyjskiej i chorwackiej: Z problemów językowego obrazu świata. Wydawnictwo Uniwersytetu Gdańskiego.

Szerszunowicz, J. (2011). Obraz człowieka w polskich, angielskich $i$ włoskich leksykalnych i frazeologicznych jednostkach faunicznych. Quick-Druk.

Wierzbicka, A. (1999). Język - umyst - kultura. Wydawnictwo Naukowe PWN.

\section{Словники}

Винник, В. (Ed.). (2003). Словник фразеологізмів украӥнської мови [ФСУМ]. Наукова думка.

\section{Bibliography (Transliteration)}

Bogacz, A. (2015). Emocje negatywne we frazeologii angielskiej i polskiej w ujęciu kognitywnym.

Retrieved from http://repozytorium.ur.edu.pl/handle/item/1202

Demydenko, H. (2016). Paralinhval'ni frazeolohizmy v ukrä̈ns'kĭ etnokul'turi. NPP Asteriks.

Dubravin, D. (2018). Psikhologiia emotsiǔ: Chuvstva pod kontrolem. Agentstvo "IPIO".

Hniezdilova, IA. (2007). Emotsiünist' ta emotyvnist' suchasnoho anhlomovnoho dyskursu:

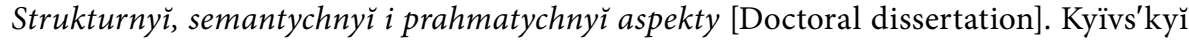
natsional'nyı̆ linhvistychnyı̆ universytet.

Huliieva, D. (2016). Komunikatyvna stratehiia prezyrstva: Na materiali anhlomovnoho kinodyskursu. Science and Education: A New Dimension: Philology, 25(105), 41-45.

Il'in, E. (2015). Psikhologiia obshcheniia i mezhlichnostnykh otnosheniǔ. Piter.

Izard, K. (2009). Psikhologiia emotsiü. Piter. 
Jakubowska-Krawczyk, K., Olechowska, P., Romaniuk, S., \& Zambrzycka, M. (Eds.). (2016). Ciało i tożsamość w ukraińskiej kulturze, sztuce, literaturze, języku. Katedra Ukrainistyki Uniwersytetu Warszawskiego; Uniwersytet Przykarpacki im. Wasyla Stefanyka.

Jasielska, A. (2015). Pozadosłowne rozumienie emocji. Poznańskie Studia Slawistyczne, 9, 255-274. https://doi.org/10.14746/pss.2015.9.15

Klyus, J. (2018). Inwektywy związane z nazwami części ciała we frazeologii polskiej i rosyjskiej: Analiza leksykalno-semantyczna. Językoznawstwo, 2018(1(12)), 145-170. https://doi.org /10.25312/2391-5137.12/2018_145-170

Krasnobaieva-Chorna, ZH. (2020). Vtorynna znakova systema tsinnisnoï kartyny svitu u frazemitsi. TOV “TVORY”.

Leskina, S. (2008). Kontsepty bezrazlichiia i prezreniia kak sostavliaiushchie peĭorativnoŭ konnotatsii angliı̌skikh i russkikh frazeologizmov. Filologicheskie nauki: Voprosy teorii i praktiki, 2008(2(2)), 65-67.

Rejter, A. (2010). Język a emocje w ujęciu glottodydaktycznym. In A. Achtelik, M. Kita, \& J. Tambor (Eds.), Sztuka i rzemiosło: Nauczyć Polski i polskiego (Vol. 2, pp. 75-83). Wydawnictwo Uniwersytetu Śląskiego; Wydawnictwo Gnome.

Seriakova, I. (2015) Kommunikativnyı̆ menedzhment konfliktnogo diskursa. Science and Education: A New Dimension: Philology, 2015(9(44)), 78-82.

Spagińska-Pruszak, A. (2003). Intelekt we frazeologii polskiej, rosyjskiej i chorwackiej: Z problemów językowego obrazu świata. Wydawnictwo Uniwersytetu Gdańskiego.

Stanko, D., \& Chendeй, N. (2018). Prahmatychni osoblyvosti reprezentatsiï prezyrstva u suchasnomu anhlomovnomu politychnomu dyskursi. Suchasni doslidzhennia $z$ inozemnoï filolohii, 2018(16), 148-155.

Stepaniuk, M. (2016). Reprezentatsiia emotsiinoho stanu khudozhn'oho personazha u zhinochomu romani: Linhvokohnityvny i hendernyı̆ aspekty: Na materiali romaniv Sh. Bronte ta E. Bronte [Doctoral dissertation]. Khersons'kyı̆ derzhavnyı̆ universytet.

Szerszunowicz, J. (2011). Obraz człowieka w polskich, angielskich i włoskich leksykalnych i frazeologicznych jednostkach faunicznych. Quick-Druk.

Uzhchenko, V. (2003). Skhidnoukraïns'ka frazeolohiia. Al'ma-mater.

Volkova, J., \& Panchenko, N. (2018). Diskursivnaia variativnost' kontseptov destruktivnykh emotsiǔ. Vestnik Rossiǔskogo universiteta druzhby narodov: Lingvistika, 22(1), 175-194. https://doi.org/10.22363/2312-9182-2018-22-1-175-194

Wierzbicka, A. (1999). Język - umyst - kultura. Wydawnictwo Naukowe PWN.

\section{Dictionaries}

Vynnyk, V. (Ed.). (2003). Slovnyk frazeolohizmiv ukraïns'koï movy [FSUM]. Naukova dumka. 


\title{
The Psychophysiological Pattern of the Emotion of Scorn: Actualisation of Invariant Features in Ukrainian Phraseology
}

\author{
Summary
}

This article analyses the specifics of the physiological and expressivebehavioural complex of the emotion of scorn in Ukrainian phraseology in the light of psychology of emotions, emotionology, linguoculturology, evaluative semantics and axiophraseological pragmatics. The study considers the emotion of scorn in its psychological diversity as exemplified in phraseological units expressing scorn in Ukrainian. The methods applied to analyse a phraseological unit include component analysis, contextual and interpretive analysis, and parametric analysis of semantic structure with a focus on the evaluative and emotive components.

\section{Psychofizjologiczny wzorzec uczucia pogardy: Aktualizacja cech inwariantnych we frazeologii ukraińskiej}

\section{Streszczenie}

Niniejszy artykuł analizuje specyfikę fizjologicznego i ekspresyjno-behawioralnego kompleksu uczucia pogardy we frazeologii ukraińskiej w świetle psychologii emocji, emocjonologii, lingwokulturologii, semantyki wartościującej i pragmatyki aksjofrazeologicznej. Przedmiotem badań jest uczucie pogardy w jej psychologicznej różnorodności na przykładzie jednostek frazeologicznych wyrażających pogardę w języku ukraińskim. Zastosowane metody analizy jednostki frazeologicznej obejmują analizę komponentów, analizę kontekstualną i interpretacyjną oraz analizę parametryczną struktury 
semantycznej ze szczególnym uwzględnieniem komponentów ewaluacyjnych i emotywnych.

Keywords: emotion of scorn; semantics; emotionology; phraseological unit; phraseology

Słowa kluczowe: uczucie pogardy; semantyka; emocjonologia; jednostka frazeologiczna; frazeologia

Zhanna V. Krasnobaieva-Chorna, Vasyl' Stus Donetsk National University, Vinnytsia, Ukraine ORCID: https://orcid.org/0000-0001-7819-8094

Correspondence: zh.krasnobaieva@gmail.com

The preparation of this article was self-financed by the author.

Competing interests: The author has declared that she has no competing interests.

Publication history: Received: 2020-02-05; Accepted: 2021-02-01; Published: 2021-11-16 